$\begin{array}{r}\text { Phinisi Integration Review } \\ \text { Vol. 1, No.2, Agustus 2018 Hal 112-127 } \\ \text { Website: } \text { http://ojs.unm.ac.id/pir } \\ \hline-45 \text { p-ISSN: 2614-2325 dan e-ISSN: 2614-2317 } \\ \hline\end{array}$

\title{
Bendungan Bili-Bili 1992-2016
}

\author{
Jamaluddin \\ Pendidikan IPS, Kekhususan Pendidikan Sejarah \\ Program Pascasarjana, Universitas Negeri Makassar \\ Email:Jamluddin.ewa.@gmail.com
}

\begin{abstract}
Abstrak. Tujuan penelitian ini adalah (i) untuk mengetahui Bagaimana latar belakang pembangunan bendungan Bili-Bili (ii) untuk mengetahui bagaimana perkembangan bendungan Bili-Bili dari tahun ke tahun. (iii) untuk mengetahui bagaimana dampak pembangunan bendungan Bili-Bili bagi masyarakat setempat. Hasil penelitian Ini menunjukkan bahwa (i) Latar belakang pembangunan Bendungan Bili-Bili, karena kota Ujung Pandang dan Sungguminasa hampir tiap tahun dilanda banjir, sehingga pemerintah melakukan kajian teknis untuk mengatasi masalah tersebut. Dari hasil kajian itu digagas perlunya membangun bendungan untuk mengendalikan banjir, memenuhi kebutuhan air bersih masyarakat kota, kebutuhan air industri, kebutuhan pertanian, dan kebutuhan energi listrik. (ii) Perkembangan Bendungan Bili-Bili berlangsung dalam tiga tahapan yaitu: pertama tahap kajian teknis tahun 1986-1988. Kedua tahap pembangunan fisik bendungan tahun 1992-1999. Ketiga tahap pengelolaan dan pemeliharaan tahun 2000 sampai sekarang. (iii) Pembangunan bendungan Bili-Bili sangat bermanfaat positif bagi masyarakat Makassar, Sungguminasa dan sebagian kecil masyarakat sekitar bendungan, akan tetapi tidak bagi yang masyarakat terkena dampak proyek bendungan Bili-Bili, yakni tidak jelasnya ganti rugi tanah dan hilangnya budaya bertani beserta tradisinya.
\end{abstract}

Kata kunci: Bendungan Bili-Bili, Penyedia Air bersih, Dampak Sosial.

Abstract . The study aims at discovering (i) the background of Bili-Bili dam construction, (ii) The development of Bili-Bili dam annually and (iii) the impact of Bili-Bili dam construction for the local people. The results of the study reveal the (i) Beckround of the construction Bili-Bili dam, because the city of Ujung Pandang and Sungguminasa almost every year hit bay floods, so the goverment conducted a technical review to evercome the problem. From the results the study was initiated the need to build dam to cope with flooding, fulfill the need of clean water for urban society, the needs of industrial water, the need of farming, and the needs of electrical energy, (ii) The development of the BiliBili dam takes place in three stages: first phase of technical studies in 1986-1988. The second phase of phisical construction of the dam in 1992-1999. Third stage of management and maintenance in 2000 until now. (iii) The Bili-Bili dam construction gave positif benefits for Makassar people, Sungguminasa people, and some of the people who live around the dam, but not for the people who good infect with the Bili-Bili dam project such as unclear land compensation and loss of farming culture its tradition.

Keywords: Bili-Bili dam, clean water provisions, social impact, unclear land. 


\section{PENDAHULUAN}

Pada bulan Desember 1975 SulawesiSelatan telah memasuki puncak musim hujan. Khususnya kota Ujung Pandang (Makassar), dan daerah tingkat II Kabupaten Gowa telah merasakan hujan yang berkepanjangan. Akibatnya dua daerah ini menjadi sasaran banjir besar. Musim hujan yang berkepanjangan tersebut berlanjut hingga bulan Januari 1976. Ada beberapa penyebab banjir tersebut, yang pertama meluapnya jaringan sungai Je'ne Berang, dan kedua; hujan lebat yang tidak sanggup diserap oleh tanah. (In Memoriam Tjambolang 1980)

Untuk merespon masalah banjir yang hampir terjadi tiap tahun, pemerintah menempuh sebuah langkah strategis. Yakni perbaikan DI (Daerah Irigasi) sebagai langkah mengelolah air yang melimpah saat memasuki musim hujan. Untuk merealisasikan langkah tersebut, pemerintah daerah yakni Gubernur Sulawesi Selatan Ahmad Lamo dan Bupati Gowa K.S. Mas'ud memasukkan rencana pembangunan ini dalam Repelita I dan II. Adapun tahap awal perencananya meliputi mainsystem dan tertiery system. (PU Sul-Sel: 1980)

Mainsystem dan tertiery system adalah sebuah upaya untuk mengoptimalkan pengaturan debit air yang besar ketika mamasuki musim hujan. Sehingga selain sebagai pengendali air saat memasuki musim hujan, juga bermanfaat bagi sektor pertanian. Proyek ini juga dikenal dengan "Crash Proyek" dengan beberapa pencapaian yaitu pengaturan air sungai Jene' Berang.

DI (Daerah irigasi) Jene' Berang pada dasarnya telah dibangun pada tahun 1926 oleh pemerintah kolonial Belanda, namun kondisinya kurang terurus pada masa-masa pasca kemerdekaan akibatnya bangunan ini terbengkalai. Sehingga proyek (Crash Proyek) tersebut juga adalah usaha perbaikan jaringan irigasi, untuk pertanian di daerah tingkat II Kabupaten Gowa pada tahun 1980-an.

Proyek tersebut juga bertujuan untuk perbaikan hasil pertanian. Tidak heran jika proyek ini masuk dalam Repelita I, dan Repelita II dengan tujuan Self Supporting bidang pangan agar memproleh predikat suasembada beras pada masa pemerintahan Orde-Baru. Anggararan proyek pengolahan irigasi Jene' Berang cukup fantastis, yaitu senilai Rp. 698.000.000 termasuk kelima terbesar di Sulwesi-Selatan pada tahun 1979/1980.
Memasuki periode selanjutnya tantangan pembangunan kota semakin tinggi. Kota-kota di Sulawesi-selatan telah mengalami pembangunan termasuk kotamadya UjungPandang (kini Makassar). Salah satu kebutuhan pokok yang harus dijawab adalah ketersedian air baku. Bukan tanpa sebab karena daerah Gowa, dan Ujung Pandang, untuk memenuhi kebutuhan airnya, sangat tergantung pada pada musim hujan (Bidang Pengairan 1992: 23).

Kota yang giat membangun, harus mempersiapkan sumber daya demi menunjang kesejahteraan masyarakat. Data yang dilansir oleh PU tahun 1990 menyebutkan kebutuhan air kota Ujung Pandang mencapai 300 liter/detik dengan jumlah penduduk 944.372 jiwa. Khusus kawasan industri Ujung Pandang membutuhkan air sebanyak 53 Liter/detik. Prediksi kebutuhan air pada tahun 2000 oleh Bidang pengairan mencaipai 3000 Liter/detik dengan tingkat pertumbuhan penduduk yang terbilang cepat. Prediksi tersebut meningkat sepuluh kali lipat dari persediaan air yang harus dipenuhi. (Bidang Pengairan 1992: 40)

Untuk menjawab tantangan tersebut, yaitu pemenuhan kebutuhan air baku, dan pengendalian banjir. Pemerintah tidak bisa hanya mengandalkan sistem pengedali air irigasi sebelumnya. Pemerintah pusat harus memberikan perhatian khusus dengan merencanankan sebuah solusi besar yaitu pembangunan DAM dan Bendungan pada sungai Jene' Berang yang membelah Kabupaten Gowa sepanjang $70 \mathrm{~km}$. Solusi tersebut tertuang dalam rencana proyek pembangunan Bendungan Besar di daerah Bili-Bili.

Proyek prestisius ini pun dimasukkan dalam Repelita V, dananya bersumber dari dari BLN (Bantuan Luar Negeri) yaitu: OECF, USAID, Belanda, Bank Dunia (IBRD), dan Bank Pembangunan Asia (ADB). Total anggaran proyek yang masuk ke SulawesiSelatan untuk sektor pengairan senilai Rp. 140.654.715.030. Pada tahun ini proyek bendungan Bili-bili baru pada tahanpan kajian teknis dan persiapan proyek. (PU, 1992)

Adapun tahap pertama yaitu pembebasan lahan untuk pembangunan bendungan Bili-Bili seluas 363 hektar, perbaikan dan pengaturan jalur sungai sejauh 12 $\mathrm{km}$, normalisasi sungai, pengerukan muara sepanjang $7,7 \mathrm{~km}$, pelindung tebing sepanjang $1,5 \mathrm{~km}$, perbaikan alur sungai pampang $4,3 \mathrm{~km}$. Tahap awal ini menelan biaya sebasar $\mathrm{Rp}$ 69.026.758. (PU Sul-Sel 1992: T 33) 
Lebih spesifik pelaksanaan proyek ini terbagi menjadi empat paket yaitu:

\begin{tabular}{|c|c|}
\hline Peket I 1986/1988 & $\begin{array}{l}\text { : Survey dan kajian } \\
\text { teknis proyek }\end{array}$ \\
\hline & Bendungan Bili-Bili. \\
\hline Paket II 1992/1993 & $\begin{array}{l}\text { Perisapan Proyek } \\
\text { berupa relokasi, } \\
\text { pembebasan lahan, } \\
\text { danperbaikan jalan } \\
\text { Malino. }\end{array}$ \\
\hline Paket III 1993/1994 & $\begin{array}{l}\text { : Pembuatan jembatan, } \\
\text { dan pelindung tebing } \\
\text { sungai. }\end{array}$ \\
\hline Paket IV 1994/1997 & Pengerjaan Coffer \\
\hline & $\begin{array}{l}\text { Dam utama, } \\
\text { Bendungan utama, }\end{array}$ \\
\hline & danBendungan sayap \\
\hline & $\begin{array}{l}\text { Kiri kanan, Spilway, } \\
\text { outlet intake, dan }\end{array}$ \\
\hline & $\begin{array}{l}\text { fasilitas Outlet. (Rafki: } \\
\text { et al. 2011) }\end{array}$ \\
\hline
\end{tabular}

Proyek pristisus pembangunan bendungan Bili-Bili merupakan salah satu proyek paling berdampak besar. Dampak yang dirasakan setelah adanya proyek ini adalah tersedianya sumber air baku bagi masyarakat kota Makassar yang saat ini (2016) berjumlah 1,2 jua orang. Selain itu berfungsi sebagai penyedia air untuk irigasi di tiga daerah: BiliBili, Kampili dan Bissua sebesar 24.585 ha di musim hujan dan 19.540 ha di musim kemarau. Disamping itu untuk pembangkit listrik tenaga air sebesar 16.30 MW, dan untuk daerah pariwisata dan perikanan darat (Tribuntimur, 2010).

Megahnya bendungan Bili-Bili yang selesai pembangunannya tahun 1999 silam telah banyak berkontribusi terhadap kehidupan masyarakat di sekitarnya, namun pada kenyataannya setiap musim hujan bendungan Bili-Bili dan daerah aliran sungai (DAS) Jeneberang sering menjadi bahan perbincangan, terlebih setelah kejadian longsor gunung Bawakaraeng pada tahun 2004, masyarakat sekitar bendungan khawatir bila terjadi musibah yang akan menimpah mereka. Tahun 2010, kembali Bili-bili dan Jeneberang ramai lagi dibicarakan menyusul guyuran hujan selama beberapa bulan, mulai soal sedimentasi, kekeruhan air, kekuatan dan kapasitas daya tampung material lumpur, dan vegetasi, yang selalu menjadi sorotan masyarakat. (Tribunnews.com. 2010)

Pada kenyataannya bendungan Bili-Bili memang memiliki fungsi yang sangat vital bagi kehidupan masyarakat, dan mempengaruhi berbagai aspek kebutuhan pokok manusia. Oleh sebab itu hadirnya Bendungan Bili-Bili penting untuk dikaji karena dianggap sebagai faktor yang menentukan keberlangsungan hidup orang banyak. Dapat dibanyangkan jika bendungan ini tidak ada, bagaimana masyarakat kota memperoleh persediaan air untuk kehidupan sehari-hari.

Selain itu ada banyak sisi-sisi sosial yang patut diungkap dari pembangunan bendungan Bili-Bili puluhan tahun silam. Seperti masyarakat yang mengalami relokasi. Mengingat luas tanah yang digunakan untuk membangun bendungan Bili-Bili (363 Ha) merupakan satu kawasan yang cukup luas. Tentunya banyak nilai-nilai sosial yang secara perlahan berubah seiring dengan hadirnya bendungan tersebut.

Artinya setiap pembangunan selalu menyisahkan dua sisi, yaitu positif dan negatif. Dari hal positifnya semua kalangan dengan general akan menjawab bahwa bendungan tersebut sangat berguna karena sebagai penyedia sumber air baku. Namun sesunggunya ada halhal kontra lainnya, juga perlu diungkapkan, mengingat Bili-Bili sebelumnya adalah tempat yang berpenghuni, tentu ada aktivitas sosial yang hilang atau "dihilangkan".

Atas alasan tersebut maka hadirnya Bendungan Bili-Bili serta mamfaat dan dampaknya bagi orang banyak patut ditulis dalam bentuk karya ilmiah dengan judul: Bendungan Bili-Bili 1992-2016.

Adapun tujuan dalam penelitian ini adalah; (1) Mendeskripsikan latar belakang pembangunan Bendungan Bili-Bili; (2) Menganalisis perkembangan Bendungan BiliBili; (3) Mendeskripsikan dampak pembangunan Bendungan Bili-Bili.

\section{METODE}

Tujuan dari penlitian ini untuk mencari dan menemukan informasi, serta menjelaskan tentang bendungan Bili-Bili kepada masyarakat melalui hasil riset sejarah. Agar tidak ada lagi kecemasan yang terjadi pada masyarakat ketika musim hujan datang. Adanya informasi tersbut dapat menjadi rujukan masyarakat untuk membendung isu-isu negatif (Hoaks) terkait isu jebolnya bendungan Bili-Bili yang sering datang ketika musim hujan tiba. 
Jenis penelitian ini adalah penelitian kualitatif dengan pendekatan sejarah. Di dalamnya menjelaskan latar belakang berdirinya bangunan Bendungan hingga dampaknya terhadap masyarakat. Selain itu bendungan dalam perjalanan sejarah manusia juga memberikan gambaran suatu peradaban yang lebih maju dalam sebuah kota. Masyaratkat kota adalah masyarakat yang memiliki konsumsi air yang tinggi dibandingkan dengan masyarakat pedesaan, oleh sebab itu penelitian ini dilakukan untuk memberikan gambaran yang objektif terkait dengan latar belakang dibangunya bendungan Bili-Bili beserta dampak/manfaatnya.

Gilbert menjelaskan bahwa "metode sejarah adalah perangkat dan kaidah sistem yang dibuat untuk membantu secara efektif dan mengumpulkan sumber-sumber sejarah, menilainya secara kritis dan menyajikan suatu sistem hasil yang dicapai pada umumnya dalam bentuk tertulis (Alfian Ibrahim, 1992: 411). Sedangkan menurut Ghottschalk metode penelitian sejarah adalah peroses menguji dan menganalisis secara kritis rekaman dan peniggalan masa lampau. Artinya rekonstruksi masa lalu harus diuji kebenarannya sebelum disajikan dalam bentuk tulisan (Pusponegoro dkk, 1992;18).

Lokasi penelitian terletak Daerah Tangkapan Air (DTA) Bendungan Bili-Bili Kabupaten Gowa. Lokasi penelitian berjarak sekitar $45 \mathrm{~km}$ dari ibukota Provinsi Sulawesi Selatan, sedangkan dari ibukota Kabupaten Gowa berjarak sekotar $30 \mathrm{~km}$. Kawasan ini dapat ditempuh dengan menggunakan kendaraan beroda empat maupun beroda dua dengan waktu kurang lebih 1 jam 30 menit dari kota Makassar. Secara geografis, Bendungan Bili-Bili terletak pada $119^{\circ} 34^{\prime} 55^{\prime \prime}$ - $119^{\circ} 56^{\prime} 40^{\prime \prime}$ LU dan $05^{\circ}$ $11^{\prime} 05^{\prime \prime}-05^{\circ} 20$ '25" LS. Bendungan Bili-Bili memiliki luas $\pm 38.407,9$ ha atau sekitar $34,07 \%$ dari luas total DAS Jeneberang yaitu 103.605,5 ha. (Google earth: 2017; Citra Satelit)

Menurut wilayah administrasi Kabupaten Gowa, Bendungan Bili-Bili terletak pada empat kecamatan yaitu Kecamatan Parangloe, Kecamatan Parigi, Kecamatan Manuju, dan Kecamatan Tinggimoncong. Adapun batas-batas Daerah Tangkapan Air Bendungan Bili-Bili sebagai berikut; (1) Sebelah Utara berbatasan dengan DAS Tallo dan DAS Maros; (2) Sebelah Timur berbatasan dengan DAS Tangka; (3) Sebelah Selatan berbatasan dengan DAS Jeneberang dan DAS Kelara; (4)
Sebelah Barat berbatasan dengan DAS Jeneberang (Bidang Pengairan, 1992).

Dalam penelitian sejarah sumber data yang menjadi pijakan dalam tulisan biasanya ada dua yaitu sumber primer dan sekunder. Dalam penelitian ini menggunakan sumber primer yang meliputi beberapa dokumen (arsip) terkait dengan data perencanan proyek pembangunan Bendungan Bili-Bili Tahun 19921999 (Proses pembangunan). Sedangkan sumber sekunder, itu terdapat buku-buku, jurnal, tesis, dan makalah, yang relevan dengan fokus penelitian. Dengan menggabungkan kedua sumber yang ada, merupakan upaya agar dapat menyalurkan tulisan yang dapat memberikan informasi situasi kelampauan mengenai proses pembangunan Bendungan Bili-Bili.

Selain melalui dokumen, penelusuran sejarah Bendungan Bili-Bili dilakukan pula melalui wawancara dengan pihak-pihak terkait yaitu perencana, pelaksana dan, pengawas dengan tujuan mengetahui proses pembangunan Bendungan Bili-Bili. Sumber tertulis acap kali tidak menerangkan makna tersembunyi dibelakang deretan kalimat yang termaktub dalam tulisan. Maka tiba waktunya bagi disiplin sejarah untuk menengok bahan lisan, bahan yang tidak tertulis, atau rekaman dalam bentuk lain. Jika emosi, suasana dan makna yang diciptakan kegiatan tidak lagi dapat dijumpai dalam bahan-bahan tertulis, kita harus menggunakan sumber lisan yang diperoleh lewat wawancara.

Untuk mendapatkan sumber sejarah lisan, maka peneliti melakukan wawancara orang yang dianggap tahu dan mengerti maupun menjadi pelaku/saksi dalam perjalanan sejarah yang merasakan dampak/manfaat pembangunan Bendungan Bili-Bili. Sumber lisan dapat memperkuat jalinan fakta yang terdapat dalam sumber tertulis berupa dokumen, walaupun perlu diperhatikan tingkat kesahihan dari narasumber yang diwawancarai sebagai sumber lisan (Kresno Brahmantyo, 2016:1)

Selain itu, sumber-sumber yang dapat dijadikan referensi adalah berupa buku-buku dan hasil penelitian terdahulu yang berhubungan dengan bendungan atau waduk. Selama data itu bisa mendukung dan dianggap relevan, maka akan dijadikan sumber data dalam penelitian ini.

Teknik pengumpulan data yang digunakan dalam penelitian ini adalah wawancara mendalam, observasi berperan aktif, analisis dokumen (content analysis). 
Adapun secara spesifik teknik pengumpulan data yang dimaksud sebagai berikut:

\section{Wawancara Mendalam (In-Depth \\ Interviewing)}

Wawancara adalah percakapan dengan maksud tertentu yang dilakukan oleh dua pihak yaitu pewawancara yang mengajukan pertanyaan dan yang diwawancarai yang memberikan jawaban atas pertanyaan itu (Moleong, 2006: 186-187). Wawancara dilakukan pada waktu dan konteks yang dianggap tepat. Pada tataran operasional, perencanaan maupun pemrograman untuk memperoleh data yang mempunyai kedalaman serta dilakukan berulangkali sesuai dengan kebutuhan yang diistilahkan dengan in-deep interviewing.

Menurut Sutopo (2006: 69) wawancara mendalam dilakukan dengan pertanyaan yang bersifat terbuka (open-ended), dan mengarah pada kedalaman informasi serta dilakukan tidak secara formal terstruktur, guna menggali pandangan subjek yang diteliti tentang banyak hal yang sangat bermanfaat untuk menjadi dasar bagi penggalian informasi secara lebih jauh, lengkap dan mendalam.

Wawancara yang dilakukan dalam penelitian ini adalah wawancara mendalam karena wawancara ini bersifat lentur dan terbuka serta dalam suasana keakraban, sehingga mengarah pada kedalaman informasi.

2. Observasi langsung berperan aktif dan pasif

Observasi berperan aktif merupakan cara khusus dan peneliti tidak bersikap hanya sebagai pengamat tetapi memainkan berbagai peran yang dimungkinkan dalam suatu situasi yang berkaitan dengan penelitiannya dengan mempertimbangkan posisi yang bisa memberikan akses yang bisa diperolehnya untuk bisa dimanfaatkan bagi pengumpulan data yang lengkap dan mendalam (Sutopo, 2006: 79-80). Observasi berperan pasif adalah suatu cara pengumpulan data dimana peneliti hanya mendatangi lokasi, tetapi sama sekali tidak berperan sebagai apa pun selain sebagai pengamat pasif, namun peneliti benar-benar hadir di lokasi (Sutopo, 2006: 77).

\section{Penulusuran Dokumen}

Penelusuran dokumen dan arsip dilakukan untuk mengumpulkan, mengidentifikasi dan menganalisis data yang bersumber dari dokumen dan arsip (Sutopo, 2006: 80-81). Dokumen tertulis dan arsip merupakan sumber data yang memiliki posisi penting dalam penelitian ini. Sumber data tertulis ini merupakan sumber data pokok dalam penelitian untuk mendukung proses menginterpretasikan setiap peristiwa yang berlangsung dalam penelitian.

Teknik mencatat dokumen ini oleh Yin digunakan untuk menemukan beragam hal sesuai dengan kebutuhan dan tujuan peneitian. Dalam melakukan teknik ini, peneliti tidak hanya mencatat isi penting yang tersurat dalam dokumen atau arsip, tetapi juga mencatat makna yang tersirat. Dokumen yang ditemukan wajib dikaji kebenarannya, baik secara eksternal (kritik eksternal) yang berkaitan dengan keaslian dokumen, dan juga internal (kritik internal) yang berkaitan dengan kebenaran isi dokumen atau pernyataan yang ada, biasanya dengan membandingkan dengan dokumen lain atau jenis sumber data lain yang berkaitan dengan isi dokumen tersebut (Sutopo, 2006: 80-81).

Setelah proses pengumpulan data dilakukan, proses selanjutnya adalah melakukan analisis data. Analisis atau penafsiran data merupakan proses mencari dan menyusun secara sistematis catatan temuan penelitian melalui pengamatan dan wawancara dan lainnya untuk meningkatkan pemahaman peneliti dengan fokus yang dikaji. Teknik analisa data yang akan penulis gunakan adalah teknik deskriptif kualitatif berlandaskan materi dan data yang berhubungan dengan topik pembahasan. Penulis menggambarkan dan menjelaskan permasalahan sesuai dengan fakta yang terjadi melalui sejumlah faktor yang relevan dengan penelitian ini, lalu ditarik sebuah kesimpulan.

Kritik Sumber. Data yang diperoleh pada tahap heuristik tidak langsung diolah menjadi tulisan, melainkan dilakukan kritik terhadap sumber terlebih dahulu. Dalam tahap ini peneliti melakukan kritik terhadap sumber yang digunakan yakni buku-buku dan dokumen atau arsip yang berhubungan dengan permasalahan yang dibahas. Pada dasarnya kritik sumber bertujuan untuk menilai otentisitas (keaslian sumber) dan kredibilitas (tingkat kebenaran informasi). Kritik sumber umumnya dilakukan terhadap sumber-sumber pertama. Kritik ini menyangkut verifikasi sumber yaitu pengujian mengenai kebenaran atau ketepatan (akurasi) dari sumber itu (Sjamsuddin, 2007: 132).

Tahapan kritik mencakup dua aspek eksternal dan internal. Aspek eksternal bertujuan untuk menilai otentisitas dan integritas sumber. Sedangkan aspek internal bertujuan untuk menilai reliabilitas dan kredibilitas sumber. 
Pada tahap kritik eksternal, peneliti melakukan pengujian untuk mengidentifikasi autentisitas pengarang dan tanggal terhadap sumber yang ditemukan. Sebagaimana yang disarankan oleh istilahnya, kritik eksternal ialah cara melakukan verifikasi atau pengujian terhadap aspek-aspek luar dari sumber sejarah (Helius Sjamsuddin, 2007: 132). Dalam hal ini buku-buku dan dokumen atau arsip yang ditemukan terlebih dahulu peneliti lakukan pengujian untuk mengetahui asal-usul sumber tersebut. Kritik eksternal harus menegakkan fakta dari kesaksian bahwa: (1) Kesaksian itu benar-benar diberikan oleh orang ini atau pada waktu ini (authenticity). (2) Kesaksian yang telah diberikan itu telah bertahan tanpa ada perubahan (uncorupted), tanpa ada suatu tambahan-tambahan atau penghilanganpenghilangan yang substansial (integritas) (Helius Sjamsuddin, 2007: 134).

Sedangkan pada tahap kritik intern, data yang sudah berhasil dikumpulkan kemudian peneliti lakukan pengujian untuk mendapatkan informasi yang dibutuhkan. Hal yang paling ditekankan disini adalah "isi" dari sumber yang diperoleh. Sumber yang diperoleh harus logis dan dapat dibuktikan kebenarannya. Selain itu data yang diperoleh dari hasil wawancara dilakukan pula penilaian terhadap informan agar peneliti mengetahui kemampuan dan kemauan informan untuk memberikan kesaksian yang dapat diandalkan. Peneliti harus yakin akan nilai moral atau kejujuran dari informan bahwa ia sedang mengatakan yang sebenarnya. Selanjutnya data yang sudah dievaluasi melalui kritik sumber diolah pada tahap selanjutnya yaitu menginterpretasikan data.

Interpretasi merupakan sebuah proses dari penafsiran sumber-sumber sejarah. Pada tahap ini peneliti melakukan analisis terhadap sumber yang telah melalui tahap kritik yang bertujuan untuk memperoleh gambaran akan peristiwa yang dibahas atas sejumlah fakta yang diperoleh dan dipadukan dengan teori maka disusunlah fakta-fakta tersebut dalam suatu interpretasi menyeluruh. Berdasarkan hal tersebut maka langkah awal yang dilakukan oleh peneliti adalah mengolah, menyusun, dan menafsirkan data yang telah teruji kebenarannya.

Hal ini dilakukan untuk memberikan tafsiran terhadap fakta-fakta yang telah dikumpulkan dan telah dikritik sehingga dapat dihubungkan antara fakta yang satu dengan fakta yang lainnya. Agar fakta-fakta itu mempunyai makna, maka mereka harus ditempatkan dalam konsep-konsep dan/atau generalisasi-generalisasi sehingga pengetahuan itu dapat diterapkan kepada orang-orang lain, pada waktu dan tempat yang lain (Helius Sjamsuddin, 2007: 22).

Dalam analisis data, fakta-fakta disusun sesuai dengan pokok permasalahan yang dikaji. Setelah fakta-fakta tersebut dirumuskan dan disimpulkan berdasarkan data yang diperoleh, maka fakta tersebut disusun dan ditafsirkan. Suatu fakta dihubungkan dengan fakta lainnya sehingga menjadi sebuah rekonstruksi yang memuat penjelasan terhadap pokok-pokok permasalahan penelitian.

Setelah melakukan proses analisis terhadap fakta-fakta yang ada, peneliti kemudian menyajikan dalam bentuk tulisan yang disebut historiografi. Dalam penulisan sejarah, wujud dari penulisan (historiografi) itu merupakan paparan, penyajian, presentasi atau penampilan (eksposisi) yang sampai kepada dan dibaca oleh para pembaca atau pemerhati sejarah (Sjamsuddin, 2007: 236). Peneliti berusaha menyajikan hasil penelitian ini dengan gaya bahasa yang menarik dan komunikatif.

Oleh karena data penelitian kualitatif umumnya diperoleh melalui wawancara, maka penyajian data model deskripsi atau cerita lebih tepat. Selain itu, data hasil pengamatan dan analisis dokumen juga disajikan secara narasi (Tohirin, 2012: 132). Historiografi atau laporan hasil penelitian merupakan tahap akhir dari suatu prosedur penelitian sejarah. Setelah melalui tahap heuristik, kritik dan interpretasi seluruh hasil penelitian yang telah diperoleh disusun menjadi suatu karya tulis ilmiah dengan pokok pembahasan proses pembangunan Bendungan Bili-Bili beserta dampak/manfaatnya. Laporan ini disusun dengan sistematika yang telah baku dan menggunakan tata bahasa yang baik dan benar. Sistematika penulisan yang digunakan sesuai dengan sistematika penulisan yang termuat dalam buku Pedoman Penulisan Tesis dan Disertasi Program Pascasarjana Universitas Negeri Makassar.

Dalam penulisan sejarah tidak hanya sekedar menampilkan data-data setelah ia dikumpulkan sesuai dengan prosedur yang ada. Namun, penulisan sejarah harus mampu menangkap makna di balik peristiwa berdasarkan fakta dan data yang terkumpul. Dengan harapan tulisan tidak hanya narasinarasi masa lalu tanpa pembelajaran yang 
relevan untuk masa depan bagi umat manusia. Deskripsi masa lalu harus mampu diungkapkan dengan harapan ia telah menjadi bagian sejarah bagi umat manusia yang hidup hari ini, sebab masa lalu adalah perpustakaan yang cukup besar bagi manusia hari ini.

\section{HASIL DAN PEMBAHASAN}

\section{A. Latar Belakang Pendirian Bendungan Bili-Bili}

Setelah melalui kajian dan telaah selama kurang lebih 13 tahun, maka pemerintah memutuskan untuk memasukkan rencana pembangunan Bendungan Bili-Bili kedalam rencana pembangunan lima tahun (Repelita) pada tahun 1989 (PU, 1992: G-9). Sebagai langkah awal pemerintah daerah yakni Gubernur Sulawesi Selatan Ahmad Amiruddin dan Bupati Gowa H.A. Azis Umar, mengupayakan relokasi penduduk yang bermukim di sekitar sungai Jenneberang Bili-Bili. Sebelum proyek dimulai pada tahun 1992, setahun sebelumnya pemindahan penduduk dalam skala kecil mulai dilakukan.Tidak ada data yang pasti berapa jumlah penduduk yang mendiami sungai Jenneberang Bili-Bili. Hal ini disebabkan oleh adanya beberapa data ganda. (wawancara Zakir Lengu)

Estimasi jumlah jiwa yang akan direlokasi dari daerah rencana genangan \pm 3000 jiwa (LSM Jarim Pedas). Pada tahun 1991 sebanyak 134 Kepala keluarga (KK), 341 Jiwa direlokasi dari tempat tinggalnya menuju Kabupaten Luwu (Pedoman Rakyat februari 1991). Hal tersebut merupakan langkah awal untuk memulai proyek raksasa tersebut. Sebagian penduduk Bili-Bili secara sukarela untuk meninggalkan kampung halamannya sebab mereka merasa terganggu apabila proyek bendungan sudah mulai dikerjakan. Itulah sebabnya mereka memilih meninggalkan tempat tersebut.

Penduduk yang tidak ingin pindah dari daerah Bendungan Bili-Bili kemudian masih menetap di dalam kawasan rencana pembangunan. Sikap keras yang ditunjukkan penduduk tersebut sebenarnya adalah bentuk protes karena tidak ingin dipindahkan dari tanah leluhurnya. Sebagian besar mereka beranggapan bahwa rencana pendirian Bendungan Bili-Bili hanya akan merugikan mereka semata (Wawancara Masyarakat terdampak Bendungan Bili-Bili).
Tahun 1992 menandai dimulainya proyek miliaran rupiah tersebut. Dalam rencana pembangunan Bendungan Bili-Bili ditaksir menelan anggaran negara sebanyak \pm 400 Miliar (PU, 2016). Proyek ini pada dasarnya tidak menggunakan dana dari APBN, melainkan menggunakan bantuan luar negeri LOAN OCEF (Jepang), yang kemudian akan dibayar dengan skema diangsur menggunakan APBN (PU, 2016).

Proyek bendungan ini dikerjakan oleh Hazama Berantas Join Operation (PU, 2016). Sebuah perusahaan kontraktor asal Jepang, yang ahli terhadap konstruksi bangunan. Menurut penuturan warga sekitar menyebutkan bahwa kontraktor Jepang tersebut sangat disiplin dalam bekerja. Salah satu contohnya yaitu dalam proses pembangunan berlaku aturan bagi pekerja yaitu dilarang merokok di dalam kawasan proyek. Sebab apabila satu puntung rokok saja tercampur dalam pasir bangunan, hal tersebut akan berbahaya dikemudian hari. Kesalahan kecil saja dapat mempengaruhi kualitas dan umur bendungan tutur pekerja proyek tersebut kepada peneliti.

Pembangunan Bendungan Bili-Bili di kerjakan oleh Kontraktor Jepang, Pekerjanya, tenaga ahlinya semua berasal dari jepang kecuali untuk proyek relokasi jalan. Mereka itu sangat ekstra hari-hati dalam mengerjakan proyek tersebut. Puntung rokok saja kalau ada yang jatuh di marahi.Tidak boleh ada kotoran yang masuk ke dalam lokasi pembangunan bendungan walaupun sangat kecil, karena dapat membahayakan keberlangsungan Bendungan Bili-Bili Kelak. (Wawancara:Zakir Lengu)

Dari keseluruhan proyek Bendungan Bili-Bili tidak semua dikerjakan oleh Hazama Berantas Join Operation. Dari lima pembagian kerja dalam Bendungan Bili-Bili hanya satu yang dikerjakan oleh Hazama Berantas yaitu Inti bendungan. Pembangunan inti bendungan yang menggunakan teknik Urugan tersebut membuat pemerintah sepertinya memilih kontraktor dari luar negeri di bandingkan dengan kontraktor lokal. Hal tersebut kemudian menepis dugaan yang berkembang di masyarakat saat itu, yang menyebut Bendungan Bili-Bili adalah bendungan Serba Jepang

Disini (Artinya Bendungan Bili-Bili) ada banyak yang terlibat dala pendirian bendungan.Tapi inti bendungan itu 
hanya di kerjakan oleh Jepang (Hazama Berantas). Untuk pekerjaan yang lain seperti relokasi jalan Malino sepanjang $16 \mathrm{Km}$ hanya di kerjakan oleh kontraktor

lokal.(Wawancara:Mappatunru).

Tudingan-tudingan yang berkembang di masyarakat dalam proses pembangunan bendungan tidak dapat disalahkan sepenuhnya, karena memang faktanya di lapangan bahwa pendanaan proyek ini pada dasarnya berasal dari bantuan Jepang yang diberikan kepada Indonesia. Kemudian yang mengerjakan proyek ini adalah kontraktor asal Jepang pula. Dari kondisi tersebut kemudian menimbulkan kecemburuan sosial di masyarakat.Apalagi masalah pekerja yang mengerjakan proyek tersebut tenaga asing bukan tenaga lokal.

Untuk menghindari kecemburuan sosial yang berkembang antara pelaku usaha dibidang konstruksi, maka pemerintah juga menggunakan kontraktor lokal.Seperti yang telah dijabarkan sebelumnya bahwa hanya proyek inti yang di kerjakan oleh kontraktor Jepang sisanya di berikan kepada kontraktor lokal. Beberapa pembagian kerja tersebut seperti pengerjaan relokasi jalan Malino sepanjang $16 \mathrm{~km}$ yang dikerjakan oleh PT. Kumagai Abadi yang dipimpin oleh H.N. Daeng Siala.

Dari pembagian kerja ini dapat lihat peran pemerintah dalam membagi proyek pembangunan Bendungan BiliBili kepada kontraktor lokal dan luar negeri, yang berdasarkan keahlian dan kemampuan kontraktor tersebut (wawancara: Jusuf Udding).

Pendirian Bendungan Bili-Bili pada akhirnya memang sangat dibutuhkan oleh masyarakat Kota Makassar dan Sungguminasa. Hal tersebut yang membuat bendungan ini harus dibangun sesegera mungkin dengan memperhatikan aspek lingkungan dan sosial masyarakat.Dengan begitu harapan kerja masyarakat sekitar bertambah besar dengan adanya dukungan infrastruktur yang dibangun oleh pemerintah.

Setelah melalui berbagai tahapan dalam pembangunan akhirnya bendungan ini selesai pada tahun 1999. Penenggelaman pertama dilakukan pada tanggal 27 November 1997. Bendungan dengan multifungsi ini mulai dialirkan pertama kali pada tanggal 6 juni 1999. Artinya pembangunan Bendungan Bili-Bili memakan waktu selama tujuh tahun lamanya. Selama tujuh tahun pula masyarakat yang akan digenangi rumahnya menjadi tidak menentu nasibnya. (Inception 2,006)

\section{B. Kendala Dalam Pembangunan Bendungan Bili-Bili.}

Satu hal yang perlu diketahui bahwa ketika berjalannya pembangunan Bendungan Bili-Bili tidak semua lahan warga telah diganti rugi oleh pemerintah.Terdapat $\pm 300 \mathrm{KK}$ yang tidak menentu nasibnya. Kondisi yang akan terjadi sekitar bendungan memang tidak pernah diduga sebelumnya oleh penduduk yang terkena proyek.

Hal ini disebabkan oleh langkah pemerintah dalam hal pembebasan lahan terkesan lamban. Hingga timbul isu-isu liar masyarakat bahwa tanah mereka tidak akan diganti rugi. Isu-isu tersebut berkembang liar di kalangan masyarakat (Wawancara Mappatunru).

Apabila mengamati hal tentang isu-isu liar yang berkembang selama pembangunan Bendungan Bili-Bili sepertinya memang berdasar. Dalam rencana proyek ini dapat dilihat bahwa pemerintah hanya menyiapkan anggaran sekitar Rp. 38.719.555,00 untuk pembebasan lahan sebanyak 365 h (P3SA 1992). Apabila diperhatikan baik-baik angka-angka tersebut sepertinya bukan untuk pembebasan lahan seperti yang masuk dalam laporan PU 1992, namun danatersebut hanya untuk pembebasan lahan yang akan didirikan bangunan inti yaitu bendungan.

Menurut penuturan warga yang terkena dampak pembangunan proyek Bendungan BiliBili, metode yang digunakan pemerintah untuk membangun Bendungan Bili-Bili sepertinya kurang bersahabat. Penyebabnya adalah pemerintah hanya membebaskan lebih dahulu wilayah yang mengelilingi perkampungan warga, dengan demikian nantinya penduduk secara sukarela akan melepaskan tanah mereka untuk kemudian ditenggelamkan (diolah dari berbagai sumber)

Dalam pelaksanaan ganti rugi tersebut pemerintah kemudian menetapkan kelas-kelas tanah yang akan diganti rugi. Terdapat empat bagian kelas tanah. Pertama kategori produktif dan memiliki sertifikat dengan harga Rp. 5.000 (Rupiah) per meter. Kedua bersertifikat dan tidak produktif dengan harga 3.000 per meter. Ketiga tidak produktif dan memiliki renceh dengan harga 2.000 per meter. Keempat tidak memiliki renceh dan tidak produktif dengan harga 1.000 per meter. (Jarim Pedas 2018) 
Keberadaan sertifikat tanah masyarakat memang sangat penting perannya. Sebab pemerintah hanya mengakui tanah-tanah yang akan diganti rugi adalah tanah yang memiliki surat-surat. Dalam kondisi ini pula lahir kecemburuan sosial diantara masyarakat yang memiliki sertifikat tanah dan masyarakat yang tidak memiliki sertifikat tanah.Mereka yang memiliki surat-surat tanah perlahan mendapatkan ganti rugi yang sebenarnya juga tidak sebanding dengan tanah mereka yang menjadi lahan proyek.

Sehingga sebagian warga lainnya kemudian bersedia menerima uang ganti rugi dari pemerintah tersebut dengan alasan daripada tidak ada sama sekali mending mereka menerima uang ganti rugi tersebut. (wawancara Iwan)

Nasib berbeda yang terjadi dalam masyarakat korban proyek tersebut tidak hanya sebatas kecemburuan sekilas saja.Namun yang terjadi adalah beberapa penduduk yang lebih dulu menerima ganti rugi karena memiliki sertifikat sepertinya taraf hidupnya juga berubah.Hal ini disebabkan oleh banyaknya uang yang diterima penduduk yang memiliki sertifikat.Sebaliknya penduduk yang belum menerima ganti rugi merasa semakin tersisihkan.Kejadian-kejadian semacam ini lumrah terjadi antara tahun 1992 hingga 1997 (Jarim Pedas 2016).

Penduduk yang tidak memiliki sertifikat tanah disebabkan oleh rasa enggan sebagian penduduk untuk mendapatkan sertifikat itu sendiri. Pemahaman tersebut terjadi ketika penduduk berusaha agar tanah mereka mendapatkan sertifikat, pada saat itu timbul wacana di masyarakat bahwa adanya sertifikat tanah akan menyebabkan mereka akan dikenai beban pajak atas tanah mereka yang memiliki sertifikat. Disitulah letak permasalahan penduduk sebelumnya.Mengapa banyak penduduk yang tanahnya tidak bersertifikat karena lebih disebabkan oleh pengetahuan yang berkembang di dalam masyarakat. (Jarim Pedas. 2016)

Penduduk kawasan Bili-Bili yang sudah ratusan bahkan ribuan tahun telah mendiami sekitar sungai Jenneberang. Mereka tidak mudah percaya kepada kebijakan pemerintah. Mereka juga tidak pernah berfikir bahwa suatu saat nanti di tempat mereka tinggal akan didirikan sebuah bendungan, dan tanah-tanah mereka akan tenggelam. Pemikiran-pemikiran demikian memang pada saat itu belum sepenuhnya
dipahami.Tatanan masyarakat yang cenderung masih menganut sistem feodal membuat masyarakat tidak begitu tertarik dengan program pengadaan sertifikat sebagai bukti kepemilikan tanah.

Pemikiran tentang kepemilikan tanah secara turun temurun yang tidak akan diganggu gugat oleh orang lain memang telah berlangsung lama, bahkan sampai pada saat Bendungan BiliBili memasuki tahun perdana dikerjakan. Penduduk tidak tahu jika yang akan mempermasalahkan kepemilikan tanahnya adalah pemerintah, dalam hal ini negara.

Situasi yang tidak mereka sangkasangka terjadi pada saat pendirian bendungan Bili-Bili, dimana pemerintah hanya akan mengganti rugi tanah bersertifikat, dan hal itu adalah masalah besar bagi penduduk yang terkena dampak proyek (wawancara: Baso Sitaba).

Dalam kondisi yang tidak menentu di dalam masyarakat bahkan terdapat beberapa calo yang mengambil keuntungan. Penduduk yang enggan berurusan dengan pemerintah terkait dengan masalah ganti rugi tanah mempercayakan kepada calo agar ganti rugi tanahnya cepat ditangani. Kasus ini tidak jarang menimbulkan masalah serius dalam masyarakat. "Akibatnya jumlah uang yang seharusnya diterima oleh warga menjadi berkurang disebabkan untuk membayar jasa calo" (wawancara: Iwan). Kejadian demikian terjadi karena sistem pembayaran ganti rugi tanah yang kurang jelas. Pemerintah seharusnya dalam melaksanakan pembayaran ganti rugi tersebut lebih detail melihat kondisi masyarakat setempat.

Apabila kita mengamati situasi di atas sebenarnya dapat dilihat bahwa pemegang kebijakan kurang persiapan dalam proyek ini. Tidak dapat sangkal bahwa kebutuhan mendesak akan adanya sebuah bendungan multifungsi di sekitar kota Makassar dan Sungguminasa memang benar adanya. Akan tetapi satu hal nampaknya tidak pernah masuk dalam kajian pendirian bendungan adalah ganti rugi tanah. Dalam rencana pendirian bendungan memang manfaatnya kebanyakan untuk masyarakat banyak, namun dalam konsep pembangunan Bendungan Bili-Bili harus pula memikirkan dampak perubahan sosial dari berdirinya bendungan tersebut.

Secara keseluruhan kasus-kasus ganti rugi tanah warga sebenarnya bukan kesalahan 
pemerintah sepenuhnya. Seperti pada kasus tidak adanya sertifikat tanah warga. Dalam kasus ini banyak juga penduduk yang sengaja tidak mengurus sertifikat karena menghindari pajak. Dalam hal ini posisi pemerintah sepertinya cukup berdasar jika dilihat dari segi hukumnya. Di lapangan misalnya, pemerintah daerah yang bersentuhan langsung dengan masyarakat terkena dampak proyek, tidak ingin salah dalam mengeksekusi sebuah kebijakan negara. Contohnya apabila pemerintah daerah mengganti rugi tanah yang tidak bersertifikat maka akan berbahaya dikemudian hari. Pemerintah daerah bisa saja mendapat ganjaran hukum jika hal tersebut dilakukan. Dalam hal ini pemerintah daerah hanya pelaksana tugas dari kebijakan pusat.

Pemerintah baik pusat dan daerah tidak ingin adanya kerugian negara dalam pembangunan proyek tersebut. Dengan alasan itu pemerintah menghindari adanya penggunaan data ganda apabila tanah yang tidak bersertifikat ikut diberi ganti rugi (Pedoman Rakyat 2000). Hal-hal yang sifatnya teknis oleh pemerintah akhirnya berkembang menjadi situasi sedemikian rupa pada masyarakat Bili-Bili. Pada akhirnya pemerintah merasa berada dalam posisi benar terkait kasus ganti rugi tanah warga terkena dampak proyek.

Disisi lain penduduk dapat dipastikan bahwa mereka tidak akan rela apabila tanahnya diambil oleh negara tanpa ganti rugi. Situasi yang begitu rumit tersebut kembali membuat masyarakat menghimpun kekuatan dalam menuntut aspirasinya. Beberapa kali masyarakat kemudian menduduki DPRD Provinsi untuk meminta kejelasan terkait status ganti rugi tanah mereka. Atas desakan yang bertubi-tubi dari masyarakat terkena dampak Proyek akhirnya pemerintah membuka pintu dialog pada tahun 1997. Pada tahun ini sebenarnya merupakan tahun awal penggenangan dilakukan, sehingga dalam kondisi kritis tersebut pemerintah pusat bisa saja menenggelamkan Bili-Bili tanpa mengganti rugi tanah warga terkena dampak proyek (Jaring Pedas 2018). Akan tetapi pemerintah daerah juga sepertinya terus berusaha agar tanah warga yang belum mendapat ganti rugi bisa mendapatkan hakhaknya.

Atas janji pemerintah terhadap status ganti rugi tanah warga situasi tegang kemudian meredah. Namun kondisi tersebut tidak berlangsung lama, penyebabnya adalah lagi-lagi pemerintah masih belum bisa mengganti rugi semua tanah yang ada dalam daerah pendirian proyek tersebut. Tercatat memasuki waktu penggenangan dan pengaliran perdana air Bendungan Bili-Bili pada tahun 1999 masih terdapat sebanyak 4.275 persil. Prona yang tengah diselesaikan (Fajar 5 Desember tahun 2000). Artinya memang ada kendala besar dalam pembebasan lahan proyek bendungan.

Pemerintah setelah didesak kemudian tidak bisa langsung mengakomodir masalah status ganti rugi tanah warga. Beberapa tahapan perlu dilalui yaitu membuatkan sertifikat tanahtanah yang akan diganti rugi, baru kemudian pemilik tanah tersebut diberi uang ganti rugi (Jaring Pedas 2018). Dalam proses ini sepertinya pemerintah kembali ke metode awalnya yaitu tindakan hati-hati tetap dilakukan demi menghindari data ganda. Apabila ini terjadi artinya bisa menyebabkan kerugian negara. Faktor lain yang juga menyebabkan begitu rumitnya proses ganti rugi tersebut adalah metode pemerintah yang tidak ingin digugat dikemudian hari oleh masyarakat setempat.

Tahun terakhir pembayaran ganti rugi setelah melewati rangkaian yang begitu banyak adalah pada tahun 2003. Pada tahun ini pemerintah tidak ingin lagi terbebani oleh masalah ganti rugi tanah warga. Disisi lain di dalam masyarakat juga membentuk suatu Lembaga Swadaya Masyarakat (LSM) yang bernama Jarim Pedas. LSM inilah kemudian hari yang banyak menyuarakan sisa-sisa pembayaran ganti rugi yang belum dibayarkan pemerintah. Oleh pihak pemerintah sendiri untuk merespon desakan masyarakat maka kemudian mendirikan sebuah tim yang bernama TIM 5 (LIMA) yang berisi pihak-pihak berkepentingan dalam hal ganti rugi tanah (Jaring Pedas 2018).

Dari kerja sama ini pemerintah secara resmi mencari semua tanah-tanah yang belum diganti rugi yang terkena dampak genangan Bendungan Bili-Bili. Dalam proses penyelesaian terakhir tersebut pemerintah menghabiskan Anggaran sebanyak Rp.1.200.000.000,00 dengan banyaksertifikat 4.275 sertifikat/Prona (Fajar, 2003). Akhirnya tanah-tanah masyarakat mendapatkan ganti rugi, setelah bertahun tahun tanah mereka ditenggelamkan.

Antara tahun 1991 hingga tahun 2003 merupakan periode tidak stabil mengenai ganti rugi tanah warga terkena dampak proyek. Pada akhirnya masyarakat Bili-Bili mendapatkan hak atas tanahnya, hal tersebut tidak lepas dari pada perjuangan seluruh lapisan masyarakat. Perjuangan tidak saja datang dari masyarakat 
setempat akan tetapi perhatian terhadap dampak proyek Bendungan Bili-Bili juga datang dari masyarakat pemerhati lingkungan lainnya. Dalam pengawalan berbagai isu Bendungan Bili-Bili setidaknya terdapat 30-an organisasi LSM yang pernah terlibat mengadvokasi Proyek Bendungan Bili-Bili (Keterangan Jarim Pedas).

Kondisi perekonomian Indonesia yang anjlok pada tahun 1998 juga berimbas sampai ketahap ganti rugi tanah masyarakat Bili-Bili. Nilai ganti rugi yang ditetapkan oleh pemerintah pada tahun 1991 dan pada tahun 2003 tidak mengalami perbedaan. Pengelompokan kelas tanah yang dikenai ganti rugi juga tidak pernah berubah. Padahal telah diketahui bersama bahwa pada tahun 1998 tinggi inflasi Indonesia mengalami kenaikan sebesar 77,6\% (Imanuddin, 2010:1). Inflasi tersebut sebenarnya telah mengubah jumlah nilai mata uang rupiah. Uang dengan jumlah Rp.5000,00 pada tahun 1996 berbeda nilainya dengan uang Rp.5.000,00 pada tahun 2003. Sementara ganti rugi tanah masyarakat terkena dampak tidak pernah berubah sama sekali. Tetap saja harga tertinggi yaitu Rp. 5000/meter dan terendah Rp.1.000/meter.

Seharusnya pemerintah ketika memasuki tahun 1999 hingga 2003 telah mengubah skema pembayaran ganti rugi. Beberapa alasannya adalah uang ganti rugi tanah warga secara nilai sangat rendah, walaupun jumlah uangnya tidak berubah. Adapun kebijakan yang mesti diambil oleh pemerintah adalah menyesuaikan ganti rugi tanah warga menurut tinggi inflasi yang terjadi, namun kenyataannya hal itu tidak pernah terjadi selama pendirian Bendungan Bili-Bili hingga selesai.

Seperti yang telah dibahas sebelumnya mengenai rumitnya ganti rugi tanah Masyarakat bendungan Bili-Bili, ternyata hal tersebut berkaitan erat dengan relokasi penduduk. Kondisi yang tidak pasti tentang daerah tujuan relokasi membuat penduduk merasa cemas, dan hal tersebut membuat penduduk memilih menetap di rumah mereka. Selain itu rumitnya ganti rugi tanah yang dibayarkan oleh pemerintah berakibat pada sikap enggan masyarakat untuk meninggalkan tanah mereka.

Data penduduk pada tiga desa yang akan digenangi oleh proyek Bendungan Bili-Bili sebanyak 14. 773 jiwa (Gowa dalam Angka 1990). Untuk memuluskan jalannya proyek Bendungan Bili-Bili maka pemerintah pada tahun 1991 merelokasi penduduk yang akan terkena dampak proyek sebanyak 341 jiwa
(Fajar 1991). Setelah pengerjaan proyek telah dimulai pada tahun 1992 pemerintah kembali mencoba melakukan relokasi penduduk sebanyak \pm 1000 jiwa (Jarim Pedas 2016).

Terdapat dua daerah untuk relokasi penduduk korban proyek Bendungan Bili-Bili yaitu: Mamuju dan Luwu. Untuk daerah Luwu menempati kecamatan Malangke, sedangkan di daerah Mamuju menepati kecamatan Baras dan Kecamatan Tommo. Secara geografis dua daerah ini sangat jauh dari Bili-Bili Parangloe.Tidak kurang jarak tempuh ke daerah relokasi tersebut memakan waktu sehari semalam perjalanan mobil, dengan Jarak sekitar $\pm 600 \mathrm{~km}$. Bahkan untuk mencapai daerah kecamatan Baras dan Tommo masih harus menggunakan perahu dari daerah Mandar. Hal ini disebabkan oleh belum adanya jalan darat yang menghubungkan daerah tersebut. Kondisi tersebut berlangsung hingga tahun 1995, karena pada tahun tersebut jalan Trans Sulawesi baru selesai dikerjakan.

Selama lima tahun berlangsung proses relokasi penduduk, sudah sebanyak \pm 10.000 jiwa telah direlokasi ke daerah Malangke, Tommo, dan Baras. Hal ini bisa saja dikatakan sebagai eksodus keluar dari tanah kelahiran penduduk yang terkena dampak bendungan. Proses relokasi tersebuttidak berlangsung sekaligus tetapi secara bertahap. Beberapa penduduk kemudian diberi tanah untuk digarap di daerah yang baru (Jaring Pedas 2018).

Perlu diketahui bahwa relokasi yang dilakukan oleh pemerintah menggunakan konsep Transmigrasi. Sehingga kondisi masyarakat yang berada pada daerah baru tersebut merupakan masyarakat plural secara budaya dan agama. Akhirnya mau tidak mau penduduk yang direlokasi tersebut harus beradaptasi dengan sesama pendatang lainnya. Hal ini kemudian memerlukan waktu untuk bagi penduduk untuk memulai hubungan sosial mereka.Seperti yang diungkap sebelumnya tentang perubahan budaya bagi penduduk terkena dampak proyek bendungan ternyata juga berimbas pada mereka yang di relokasi jauh dari daerah asalnya. Misalnya di daerah relokasi transmigrasi tersebut tidak terdapat sawah maka mereka terpaksa menekuni profesi lain yang bisa menunjang kehidupannya.

Apabila dicermati mengenai proses relokasi penduduk terkena dampak menggunakan konsep transmigrasi sepertinya tidaklah tepat. Penyebabnya adalah pertama penduduk yang terkena proyek tersebut tidak 
seharusnya dipindahkan jauh dari tempat tinggal semula agar kebisaan dan tradisi mereka tidak cepat hilang. Kedua penduduk yang terkena dampak proyek tidak seharusnya diikutkan dalam program transmigrasi, karena mereka itu adalah korban dari pembangunan yang semestinya mendapatkan tempat khusus yang lebih layak.

Secara teknis program transmigrasi adalah program nasional yang ditujukan untuk daerah padat penduduk dan korban bencana. Kebijakan pemerintah yang menggabungkan penduduk terkena dampak proyek kedalam program transmigrasi sepertinya merupakan tindakan menghemat biaya. Dapat dibayangkan berapa banyak uang yang dibutuhkan oleh pemerintah jika harus membeli lahan baru untuk penduduk tersebut. Sedang pada saat bersamaan terdapat proyek pemerintah yang dapat digunakan untuk menghemat biaya. Tidak perlu lagi membeli tanah relokasi karena proyek transmigrasi memanfaatkan kawasan hutan yang baru dibuka.

Masalah baru kemudian lahir dari konsep relokasi yang tidak terencana sebelumnya. Masalah tersebut adalah banyaknya penduduk yang kembali dari daerah Transmigrasi tersebut karena merasa tidak nyaman dengan kondisi daerah relokasi.

Ada beberapa faktor yang menyebabkan hal tersebut bisa terjadi :

a. Lingkungan Daerah Relokasi Belum

Dipersiapkan Secara Maksimal

Daerah relokasi yang menggunakan konsep Transmigrasi secara teknis bukanlah daerah yang betul-betul siap untuk ditempati.Masyarakat masih perlu menebang pohon di tengah belukar untuk keperluan perkebunan.Hal tersebut seharusnya telah dilakukan oleh pemerintah jauh-jauh hari sebelum daerah tersebut ditempati oleh masyarakat korban bendungan Bili-Bili. Disisi lain daerah yang menjadi tujuan relokasi merupakan rawa-rawa yang tidak layak di tempati oleh warga (Diolah dari berbagai Wawancara)

b. Letak Geografis Jauh dari Kampung

Halaman.

Daerah relokasi yang jauh dari tempat tinggal sebelumnya membuat penduduk yang terkena dampak memilih meninggalkan daerah relokasi tersebut. Hal ini terjadi pada beberapa orang yang terpisah dari keluarganya disebabkan oleh berdirinya bendungan Bili-Bili. Beberapa keluarga terkena dampak yang memilih tinggal di sekitar daerah genangan. Tindakan tersebut memberikan harapan bahwa tinggal di kabupaten Gowa lebih baik dari pada harus tinggal di kampung orang (Wawancara Nasaruddin)

c. Akses Transport dan Logistik yang Sulit

Daerah relokasi korban Bendungan BiliBili sesungguhnya bukanlah daerah yang berpenduduk ramai. Apalagi untuk menjangkau daerah tersebut dibutuhkan waktu berhari-hari lamanya. Waktu tempuh yang cukup lama membuat kebutuhan pokok sulit didapatkan. Akhirnya penduduk yang tinggal di daerah relokasi Transmigrasi padamemilih pulang kampung. Daripada tinggal di daerah yang baru dibuka tersebut sebagian besar penduduk memilih mencari pekerjaan di kota Makassar atau daerah lannya. (Diolah dari: wawancara dan Arsip)

Tidak semua penduduk yang direlokasi di daerah transmigrasi pulang ke kampung halamannya. Di perkirakan Jumlah yang kembali ke daerah Bili-Bili sekitar \pm 500 jiwa. Penduduk yang mampu bertahan di daerah yang baru dengan segala keterbatasan masih tetap memilih daerah transmigrasi. Tidak sedikit cerita sukses mereka yang bertahan di kampung orang, namun tidak sedikit pula yang cerita kegagalan yang mereka rasakan di daerah yang baru mereka kenal tersebut (Jaring Pedas 2018).

Penduduk yang tidak tahan hidup di daerah transmigrasi kemudian kembali ke kampung halamannya, dan membuka lahan di sekitar Bendungan Bili-Bili yang sudah jadi. Lokasi pembukaan lahan tersebut berjarak 14 $\mathrm{km}$ dari bendungan utama. Pembukaan lahan tersebut dilakukan dengan membebaskan lokasi milik dari PT. Perhutani.Penduduk kemudian membeli tanah dari PT. Perhutani dengan harga 7000/meter.

Apabila kita telaah lebih dalam maka sesungguhnya angka pembelian tanah tersebut cukup mahal. Penyebabnya karena harga tanah yang dibayar oleh pemerintah hanya Rp.10005000 saja (Wawancara Iwan). Semestinya perhutani dan pemerintah bersinergi agar harga tanah tersebut sesuai dengan ganti rugi tanah penduduk yang terkena proyek. Pada akhirnya masalah lagi yang lahir dari imbas relokasi yang tidak terencana tersebut.

Disisi lain bagi penduduk yang tanahnya sedikit dan ganti ruginya juga tidak jelas itulah yang kemudian memiliki masalah sosial yang cukup serius. Penduduk yang tidak memiliki tanah untuk digarap pada akhirnya menjadi 
buruh tani di persawahan penduduk di kecamatan lain. Tidak sedikit juga penduduk yang menjadi buruh di kota Makasar dan pada akhirnya penduduk kota semakin bertambah dan persaingan kerja semakin tinggi membuat mereka secara perlahan tersingkir (Pedoman Rakyat Januari 2005).

Pembangunan Bendungan Bili-Bili selesai pada tahun 1999. Dengan kehadiran Bendungan Bili-Bili ini membuat warga kota Makassar dan Sungguminasa tidak lagi kesulitan air bersih. Khusus untuk petani sudah bisa bertani sepanjang tahun. Itulah dampak positif keberadaan Bendungan Bili-Bili di kecamatan Parangloe.Menurut Kementerian Pekerjaan Umum Bendungan Bili-Bili dapat mengendalikan banjir sebesar $2.200 \mathrm{~m}^{3} /$ detik hingga $1.200 \mathrm{~m}^{3} /$ detik. Selain itu dapat menyediakan air baku sebanyak 3300 m²/detik. Bendungan Bili-Bili dalam kajian teknisnya dapat mengendalikan banjir dalam skala 50 tahun (Pekerjaan umum, 2016: 2).

Kehadiran bendungan ini sangat penting artinya bagi semu kalangan.Sehingga berdirinya bendungan ini merupakan solusi besar bagi ketersediaan air untuk masyarakat. Warga kota tidak lagi bingung dengan ketersediaan air bersih kecuali bendungan itu sudah tidak berfungsi sebagaimana mestinya. Menarik untuk mengetahui perkembangan bendungan tersebut, sebab menurut Kementerian Pekerjaan Umum Sebelumnya bahwa bendungan ini dapat mengendalikan banjir dalam skala 50 tahun (Pekerjaan Umum 2016: 2). Artinya setelah 50 tahun fungsi bendungan akan diperbaiki lagi dari berbagai potensi kerusakan seperti tingginya endapan lumpur yang dapat berpengaruh terhadap daya tampung air di waduk.

Kenyataan yang terjadi hasil kajian tersebut tidak selalu berjalan mulus, adakalanya kondisi alam berkata lain. seperti ketika terjadi longsor Gunung Bawakaraeng pada tahun 2005. Hal ini berdampak pada tingginya kiriman lumpur yang terbawa arus dari hulu sungai. Menurut Gubernur Amin Syam pada tahun 2005 sudah terdapat 4 juta meter kubik sedimen lumpur yang terdapat di Bendungan Bili-Bili Apabila kondisi itu terus di biarkan maka Bendungan Bili-Bili diperkirakan akan penuh dengan lumpur 10-20 tahun ke depan (Pedoman Rakyat, Januari 2005).

Untuk mengatasi masalah tersebut pemerintah kemudian berencana membangun Cek Dam di bagian hulu bendungan sebanyak sepuluh buah. Dalam proses pencegahan kerusakan bendungan tersebut pemerintah Provinsi kembali menggaet kontraktor asal Jepang, yang dipimpin oleh Mansye. Mansye telah berpengalaman mengatasi masalah endapan lumpur untuk keberlangsungan bendungan. Beberapa bendungan yang telah diatasinya adalah Waduk Darma Jawa Barat yang dibangun pada tahun 1954 dan masih bertahan hingga kini berkat hasil kerjanya (Pedoman Rakyat, Januari 2005).

Pembangunan Cek Dam atau Sam pocket mulai dibangun pada tahun 2006 dengan anggaran sebesar Rp 49.868.697.585. Sabo dam tersebut berfungsi sebagai penghalau lumpur yang semakin marak terjadi ketika musim hujan telah tiba. Dengan adanya Sam Pocket tersebut keberlangsungan bendungan bisa lebih lama dibandingkan tidak ada yang menghalangi lumpur tersebut masuk ke waduk Bili-Bili. Akan tetapi dalam realisasi pembangunan Sam Pocket Daerah Aliran Sungai Bili-Bili pemerintah hanya membangun delapan buah Sam Pocket. Tidak disebutkan apa saja alasannya mengapa pembangunan tersebut berkurang dua buah. Besar kemungkinan tindakan tersebut telah melalui hasil kajian perusahaan yang mengerjakan proyek tersebut (Inception Report 2006: 19\& Fajar 2005).

Kesadaran penduduk di sekitar Bendungan Bili-Bili sangat mempengaruhi keberlangsungan bendungan. Beberapa hal yang dapat memperpendek umur bendungan seperti Ilegal Sand Mining (Galian C) sangat berpotensi terhadap dampak kerusakan lanjutan. Tambang galian $\mathrm{C}$ pada dasarnya membuat tanah dan pasir yang berada jalur penerimaan air menjadi lumpur pada saat musim hujan tiba. Kontur tanah yang berubah ketika pasirnya terus digali akan menyebabkan longsor dikemudian hari (Inception Report 2006:17).

Selain itu munculnya daratan di sekitar waduk pada musim kemarau membuat masyarakat berlomba-lomba untuk memanfaatkan lahan tersebut. Sepintas lalu memang aktivitas masyarakat tersebut tidak berbahaya bagi bendungan, akan tetapi masalah yang sesungguhnya ada pada penggunaan pestisida pada tanaman mereka. Hal itu telah dikaji jauh-jauh hari sebelum bendungan itu difungsikan Menurut Dr. Kahar Mustari (Ahli Lingkungan Hidup) bahwa pencemaran lingkungan Bendungan sangat berbahaya bagi penduduk kota. 
Pada akhirnya kesadaran masyarakat di sekitar Bendungan Bili-Bili merupakan benteng terakhir keberlangsungan bendungan BiliBili.Pada saat ini penduduk seharusnya di berikan kompensasi bagi yang tinggal di sekitar bendungan agar mereka secara berkelanjutan bisa menjaga dan melestarikan bendungan tersebut.

Kondisi sesungguhnya yang terjadi saat ini di sekitar bendungan menurut peneliti adalah kurangnya perhatian pemerintah. Dapat dibayangkan bahwa mereka yang dulu kehilangan tanahnya demi pembangunan proyek bendungan tidak mendapatkan apa-apa dikemudian hari. Sementara yang menikmati buah manis dari proyek Bendungan Bili-Bili adalah warga Makassar yang berjumlah 1,6 juta jiwa. Sementara penduduk Bili-Bili yang tinggal di sekitar bendungan tidak menikmati air Bedungan Bili-Bili. Baru pada tahun 2007 penduduk mendapatkan air bersih melalui sungai PekkoLompo yang dibendung dan itu bukan dari Bendungan Bili-Bili. Sebelum itu dari tahun 1999 hingga 2007 penduduk yang terkena dampak proyek harus mengambil air bersih sangat jauh dari tempat tinggal mereka.

Apabila pemerintah tidak memberikan perhatian khusus kepada mereka, maka bisa saja penduduk akan acuh terhadap kondisi lingkungan yang ada. Hal itu peneliti buktikan bahwa saat ini masih sering terjadi berbagai macam tindakan masyarakat yang bisa mengancam keberadaan Bendungan Bili-Bili. Diantaranya seperti tambang Galian $\mathrm{C}$, tidak sulit menemukan penambang di daerah aliran sungai Jenneberang. Demikian juga dengan aktivitas bertani di aliran sungai, tidak sulit menemukan orang yang bertani di aliran sungai ketika musim hujan.

\section{Dampak Bagi Masyarakat Sekitar}

\section{Dampak Sosial}

Pada awal pembangunan Bendungan

Bili-Bili tahun 1992 pemerintah hanya merelokasi warga sebanyak 341 Jiwa dari 3000 Jiwa yang terdaftar sebagai penduduk desa BiliBili kecamatan Parangloe (Pedoman Rakyat 19 februari 1991). Dari sini dapat ditarik gambaran bahwa proyek Bendungan Bili-Bili sejatinya kurang memperhatikan penduduk yang terkena dampak pembangunan tersebut. Pemerintah dalam hal ini tidak mempersiapkan segala sesuatunya sebelum pembangunan dimulai. Seharusnya lokasi proyek pendirian bendungan tersebut terlebih dahulu dikosongkan sebelum pengerjaan proyek.

Hal yang memang tidak diduga sebelumnya benar-benar terjadi bahwa warga yang selama ini terkena dampak dari pada pendirian bendungan mulai resah. Mereka kemudian mengajukan aspirasi mereka kepada pihak pemerintah baik pusat dan daerah. Di masyarakat kemudian berkembang suatu isu yang tidak menguntungkan masyarakat dan pemerintah. Isu-isu tersebut berupa ganti rugi yang dianggapnya tidak akan dibayarkan oleh pemerintah. Berangkat dari kondisi tersebut membuat masyarakat sekitar bereaksi dengan melakukan aksi demonstrasi ke Kantor DPR Sulawesi-Selatan pada tahun 1993.

Idealnya proyek Bendungan Bili-Bili didirikan jauh-jauh hari telah terdapat sebuah kajian yang mendalam mengenai kondisi masyarakat yang terkena dampak proyek. Hingga memasuki tahun pembangunan pada tahun 1992 belum ada sebuah kebijakan yang pasti mengenai ganti rugi masyarakat terkena dampak proyek."Nanti pada tahun 1996 baru ada titik terang mengenai status tanah warga yang terkena dampak proyek, itupun hanya bagi tanah yang memiliki surat-surat"(wawancara Rais).

Apabila kita merujuk pada hasil kajian tentang manfaat yang dapat diperoleh ketika bendungan tersebut selesai dibangun, maka tidak akan ditemukan sebuah kemudaratan. Hal tersebut disebabkan karena proyek tersebut menyangkut hajat orang banyak. Dapat dibayangkan penduduk kota Makassar pada tahun 1990 sudah mencapai 994.372 jiwa. Sebuah angka yang sangat fantastis, jika penduduk sebanyak itu dalam memenuhi kebutuhan air bersihnya mengandalkan air tanah (Air Sumur), berarti hanya menunggu waktu saja kualitas tanah di kota Makassar akan rusak. Disisi lain penduduk yang jelas-jelas terkena dampak proyek pembangunan bendungan seolah tidak diperhatikan keberlangsungan kehidupannya.

Secara jumlah penduduk Bendungan Bili-Bili memang sedikit jumlahnya dibanding dengan penduduk yang akan mendapatkan manfaat bendungan. Dalam hal ini ibarat mengorbankan sesuatu yang kecil untuk keselamatan sesuatu yang besar. Itulah kenyataan yang terjadi dalam proses pembangunan bendungan Bili-Bili. Masyarakat yang kemudian terdesak dengan adanya proyek tersebut mencoba menghimpun kekuatan 
mencari keadilan dari pemerintah.Dalam penuturan masyarakat setempat mengatakan bahwa mereka hampir tiap hari mengadakan konsolidasi terhadap kejelasan status tanah masyarakat yang terkena dampak proyek.

Apa yang diungkapkan oleh Zakir Dg Lengu di atas setidaknya telah memberikan gambaran bahwa pembebasan tanah di Bili-Bili belum tuntas dilakukan oleh pemerintah saat itu. Proyek sudah berjalan sementara masyarakat masih belum mendapatkan hak-hak mereka atas tanahnya. Pada dasarnya sebagian besar mereka telah menerima pendirian bendungan itu. Hal tersebut disebabkan oleh adanya sebuah kondisi di dalam masyarakat Bili-Bili, bahwa mereka tidak mungkin melawan kehendak pemerintah dalam mendirikan bendungan tersebut. Proyek itu adalah proyek nasional tidak mungkin gagal terlaksana. Permasalahan yang ada dan paling menyita pikiran masyarakat Bili-Bili itu hanya status ganti rugi tanah mereka.

Kondisi yang terjadi pada saat memasuki tahun pengerjaan proyek adalah masih terdapat sekitar \pm 2600 jiwa yang menetap di kawasan pembangunan proyek tersebut. Hal ini tentu sewaktu-waktu dapat menjadi penghambat pengerjaan proyek tersebut.Penyebabnya warga yang tidak terima terhadap pembangunan Bendungan Bili-Bili sewaktu-waktu bisa saja mengajukan ketidakpuasan mereka terhadap proyek tersebut.

2. Dampak Budaya

Pembangunan Bendungan Bili-Bili tidak hanya berdampak secara sosial di masyarakat terkena dampak proyek. Dampak lain yang juga sangat di rasakan oleh warga Bili-Bili kecamatan Parangloe adalah dampak perubahan budaya. Setelah proyek Bendungan Bili-Bili mulai berjalan pada tahun 1992 sebenarnya pada saat itu telah terjadi perubahan sosial dan budaya di dalam masyarakat.Warga yang selama ini dekat dengan sungai perlahan merasakan perubahan lingkungan yang drastis di sekitar mereka.

Perubahan lingkungan tersebut mulai terjadi ketika masyarakat Bendungan Bili-Bili mulai kehilangan tempat tinggalnya akibat proses penenggelaman kawasan Bendungan. Hal ini merupakan pergeseran yang terjadi begitu cepat di dalam masyarakat bendungan Bili-Bili. Penduduk yang dulunya akrab dengan budaya bertani dengan sawah yang begitu luas, terpaksa berubah haluan dengan menekuni profesi lain (Fajar1995). Penyebabnya adalah penduduk yang tanahnya ditenggelamkan tidak lagi memiliki sawah yang bisa diolah.Sementara pemerintah tidak mempersiapkan sawah baru bagi mereka.

Hadirnya Bendungan Bili-Bili sangat besar dampaknya bagi penduduk yang dahulu mendiami daerah bendungan tersebut. Penduduk yang telah meninggalkan daerahnya berusaha mengenal daerah yang baru mereka diami. Perlu diketahui bahwa tidak semua penduduk Bili-Bili yang terkena dampak proyek itu ikut transmigrasi banyak diantara mereka yang pergi meninggalkan Bili-Bili menuju daerah baru yang dianggap bisa ditempati untuk melanjutkan hidup. Sebagian penduduk lagi masih menetap di sekitar bendungan Bili-Bili.Walaupun mereka pindah tinggal di sekitar bendungan, tetap saja mereka mengalami perubahan budaya yang begitu keras.

\section{DAFTAR RUJUKAN}

Ahmad Rifqi Asrib Dkk, 2011. South Sulawesi. Dampak Longsoran Kaldera Terhadap Tingkat Sedimentasi di Waduk Bili-Bili Provinsi Sulawesi Selatan. Jurnal Ann Anesthesiol Fr.

Apra, Rusman. 2015. Estimasi Penutupan/Penggunaan Lahan Pada Tahun 2019 Di Daerah Tangkapan AirBendungan Bili-Bili. Makassar: Universitas Hasnuddin.

Bidang pengairan.1992. Profil Kegiatan Pembangunan Bidang Pengairan di Provinsi Sulawesi-Selatan.Makassar: bagian Proyek di Sulawesi-Selatan.

Badan Pusat Statistik.2015.Statistik Pertanian Tanaman Pangan dan Hortikultura KabupatenTakalar. Takalar: BPS.

Badan Pusat Statistik. 2015. Jumlah penduduk Kota Makassar tahun 2015. Makassar: Badan Pusat Statistik.

Dep. Pekerjaan Umum. 1995.Bendungan Besar Di Indonesia Jakarta: Departemen Pekerjaan Umum.

Dinas Pekerjaan Umum Provinsi SulawesiSelatan.1980.Memory Ir. Lateko Tjambolang Kepala Dinas Pekerjaan Umum Provinsi Sulawesi-Selatan 1969-1080.

Faisal, Muh. 2010. Arahan Penggunaan Lahan Berbasis Rendah Emisi Karbon dan Peningkatan Volume Air Lariang di Daerah Tangkapan Air Bendungan Bili-Bili. Makassar : Universitas Hasnuddin 
Khomariyatika, Tattit, Eram Tunggul Pawenang. 2011. Kualitas Bakteriologis Air

Sumur Gali.Jurnal Kesehatan

Masyarakat.

Pemerintah Republik Indonesia. 2010.

Peraturan Pemerintah Republik

Indonesia Nomor 37 Tahun 2010

Tentang Bendungan .

\section{Dokumen}

Perencanan Sub Dinas Pengairan DPUP Sul-Sel Juli 1986- dikutip dari atlas for south Sulawesi DHV April 84 dan Bapeda Sulawesi-Selatan 85/86

Nota Keuangan Negara tahun 1998.Tentang Krisis dan tinggai inflasi Republik Indonesia.

Kementerian Pekerjaan umum dan Perumahan Rakyat. Direktorat Jenderal Sumber daya air Balai besar Wilayah Sungai Pompengan Jenneberang. Laporan Singkat Bendungan Bili-Bili. 2016.

Proyek Kegiatan pembangunan Bidang pengairan di Provinsi Sulawesi Selatan. 1992.

Proyek Penelitian Perencanaan Pengembangan Sumber-Sumber Air (P3SA) Pusat Bagian Proyek di SulawesiSelatan.PU. 1992.

Dokumen Investasi dan Pencapaian hail pembangunan pengairan Tahun Anggaran 1990/1991.

Dokumen Jumlah dan lokasi Irigasi di Sulawesi Selatan.PU 1990.

Dokumen Kondisi Lahan Persawahan di Sulawesi-Selatan. PU. 1990.

Kotamadya dalam Angka 1990, Ujung pandang (Makassar) : Badan Pusat Statistik Kotamadya Ujung Pandang.

Makassar Dalam Angka 1990.Luas dan Produksi padi sawah menurut Kabupaten/ Kotamadya SulawesiSelatan tahun 1990.

\section{Media Cetak dan Online}

Tribunnews.com.2010. Isu Bili-Bili Retak Akibat Gempa Belum Terbukti. Laman: URL http://www.tribunnews.com/regional/2 010/12/13/isu-bilibili-retak-akibatgempa-belum-terbukti. (accessed 11.4.17)

Fajar.Agustus 1992. Kahar Mustari: Antisipasi Masalah Lingkungan Hidup Bili-Bili. Makassar: Fajar.

Fajar. Selasa 5 Desember 2000. Bupati Gowa Janji Selesaikan Ganti rugi Bili-Bili. Ujungpandang: Fajar.
Fajar. Selasa 8 Agustus 1995.Dari Proyek Bendungan Bili-Bili: Gowa Penyangga Ujung Pandang Masa Depan. Ujungpandang: Fajar.

Fajar. 22 November 2005. Percepat Pembangunan Sabodam. Makassar: Fajar. 